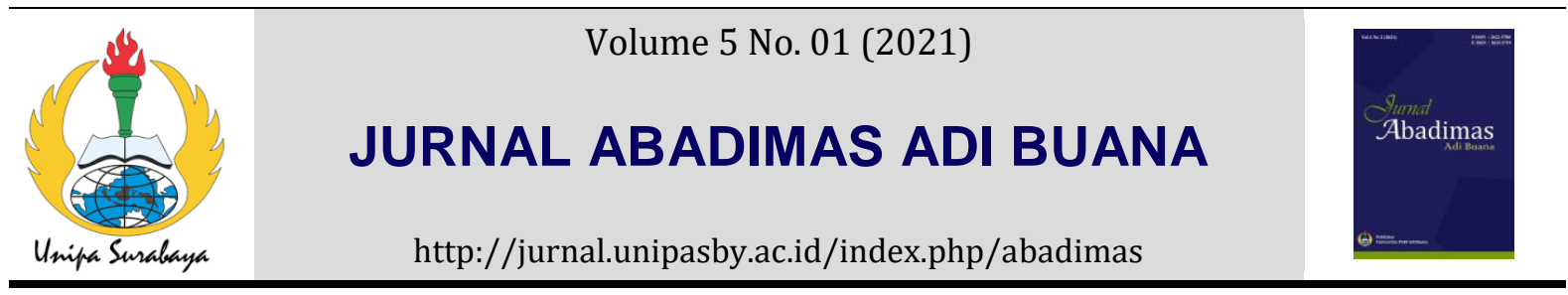

\title{
PELATIHAN PERANCANGAN BUSANA PELINDUNG DIRI UNTUK FESYEN SEHARI-HARI DI ERA NEW NORMAL BAGI INDONESIAN FASHION CHAMBER COMMUNITY DI SURABAYA
}

\author{
Dewa Made Weda Githapradana ${ }^{*}$, Rahayu Budhi Handayani², Fabio Ricardo Toreh ${ }^{3}$ \\ ${ }^{1}$ Program Studi Fashion Product Design and Business, Universitas Ciputra Surabaya, Indonesia \\ *email: weda.githa@ciputra.ac.id
}

\begin{abstract}
Informasi Artikel Abstrak
Kata kunci:

Personal Protective

Equipment

(PPE),

Desain, Fesyen .

Diterima: 13-01-2021

Disetujui: 19-05-2021

Dipubikasikan: 14-07-

2021

Pandemi Covid-19 yang merebak sejak Maret 2020 di Indonesia telah merubah sistem sosial dan tatanan kehidupan masyarakat. Setiap individu harus dapat beradaptasi terhadap tatanan normal baru dalam upaya bertahan terhadap krisis yang ditimbulkan sebagai dampak pandemi. Dampak krisis juga dialami oleh pelaku industri fesyen di Surabaya yang tergabung dalam Indonesian Fashion Chamber (IFC) Community Surabaya. Persoalan yang dihadapi mitra adalah perubahan dan krisis akibat pandemi Covid-19 menempatkan mitra pada keadaan sulit baik dalam permasalahan produksi, modal, dan menurunnya jumlah permintaan barang dan jasa sebagai akibat perubahan gaya hidup masyarakat. Program PKM diselenggarakan atas respon permasalahan yang dihadapi oleh mitra. Solusi yang ditawarkan adalah memberikan sebuah pelatihan mulai dari desain, produksi, hingga sistem pemasaran yang sesuai dengan era new normal. Materi pelatihan berupa perancangan Personal Protective Equipment (PPE) untuk kebutuhan fesyen sehari-hari. Pelaksanaan kegiatan pelatihan dilakukan dalam 3 tahap pertemuan secara daring dalam kurun waktu 4 bulan. Hasil pelatihan berupa produk busana PPE fesyen siap pakai yaitu outer dan masker. Kegiatan pelatihan mampu menjadi salah satu alternatif solusi bagi mitra dalam beradaptasi dengan perubahan yang terjadi sebagai akibat pandemic covid19.
\end{abstract}

Keywords :

Personal Protective

Equipment (PPE),

Design, Fashion

\section{Abstract}

The Covid-19 pandemic that broke out in March 2020 in Indonesia has changed the social system and the order of people's lives. Each individual must be able to adapt to the new normal order to survive the pandemic crisis. The fashion industry practitioners in Surabaya, who are members of the Indonesian Fashion Chamber (IFC) Community Surabaya have also had the impact of the crisis. The problems faced by partners because of the Covid-19 pandemic are placing partners in a difficult situation in terms of production, capital, and decreased demand for goods and services as a result of shifting in people's lifestyles. The PKM program is held in response to problems faced by partners. The solution offered is to provide training from design, production, to marketing systems that suitable for the new normal era. The training subject was in the form of personal protective equipment (PPE) design for daily fashion needs. The training activities were carried 
out in 3 stages of online meetings over a period of 4 months. The result is ready-to-wear PPE fashion products, such as jackets/ outer and masks. This can be an alternative solution for partners in adapting to the changes in the future.

\section{PENDAHULUAN}

Pandemi Covid-19 yang merebak sejak Maret 2020 di Indonesia telah merubah sistem sosial dan tatanan kehidupan masyarakat. Setiap individu harus dapat beradaptasi terhadap tatanan normal baru dalam upaya bertahan terhadap krisis yang ditimbulkan sebagai dampak pandemi. Krisis yang ditimbulkan tidak terbatas pada krisis kesehatan saja, namun dampaknya meluas ke berbagai sektor termasuk perekonomian. Industri fesyen juga mengalami dampak signifikan dan mengalami perubahan sebagai akibat pandemic covid-19 (Beltrami et al., 2020). Tajuk berita CNBC Indonesia memaparkan bahwa Indonesia telah mengalami kontraksi produk domestik bruto (PDB) pada kuartal II-2020 dan berlanjut ke kuartal III-2020. Pernyataan Ibu Sri Mulyani mengenai Indonesia diperkirakan memasuki resesi pada akhir September 2020 merupakan indikasi bahwa roda perekonomian di Indonesia sedang mengalami hambatan (Fauzia, 2020). Kendala perekonomian sebagai akibat pandemi covid-19 berdampak negatif bagi usaha kecil menengah (UKM). Berdasarkan data tajuk berita CNBC Indonesia, unit usaha kecil UKM mengalami penurunan pendapatan sebesar 84,2\% (Hastuti, 2020). Berdasarkan fakta tersebut, pelaku UKM di bidang fesyen khususnya IFC Community di Surabaya juga merasakan dampak negatif dari pandemi Covid-19.

Persoalan yang dihadapi mitra adalah perubahan dan krisis akibat pandemi Covid-19 menempatkan mitra pada keadaan sulit baik dalam permasalahaan produksi, modal, dan menurunnya jumlah permintaan barang dan jasa sebagai akibat perubahan gaya hidup masyarakat. Permasalahan yang ditemukan mencakup beberapa hal sebagai berikut:

1. Pembatasan kegiatan masyarakat telah merubah gaya hidup, sehingga permintaan jumlah barang dan jasa tertentu menurun.

2. Penurunan permintaan mengakibatkan pemasukan pelaku bisnis berkurang sehingga menghambat proses produksi dan berjalannya bisnis secara normal.

3. Pembatasan dan penutupan toko fisik serta pembatasan kegiatan pameran dan fashion show telah membatasi ruang pemasaran UKM di bidang fesyen.

4. Pasar lebih memilih untuk berbelanja kebutuhan primer dalam masa krisis. Berdasarkan alasan tersebut pelaku UKM banyak yang beralih untuk menyediakan kebutuhan yang dibutuhkan pasar seperti produk-produk pelindung diri yang bukan merupakan ekspertis mereka sebelumnya.

Pelaksanaan kegiatan pengabdian masyarakat berupa pelatihan pengembangan produk busana pelindung diri untuk kebutuhan fesyen sehari-hari merupakan salah satu solusi alternatif bagi krisis yang dihadapi oleh pelaku UKM fesyen yang tergabung dalam IFC Community Surabaya. Pandemi 
telah merubah perilaku konsumen dalam mengkonsumsi barang dan jasa (Wright, Oliver; Blackburn, 2020). Berdasarkan riset lembaga peneliti trend WGSN mengkategorikan tipikal pasar selama hingga pasca pandemik menjadi 5 kategori yang 3 diantaranya menjadi acuan dalam melaksanakan program PKM. Tiga kategori prilaku pasar yang dimaksud adalah konsumen lebih hemat dan efisien dalam urusan finansial, lebih fokus pada masalah kesehatan, dan lebih mementingkan keselamatan dan proteksi diri. Berdasarkan prediksi tersebut produk busana pelindung diri (personal protective equipment) untuk kegiatan sehari-hari menjadi alternatif produk fesyen yang dibutuhkan oleh pasar saat ini.

Pandemi telah menjadi bagian dari kehidupan saat ini, pemerintah pun telah melakukan tindakan pencegahan terhadap infeksi yang menular. Tampaknya masyarakat mengikuti aturan baru yang diterapkan, seperti: social distancing, rajin mencuci tangan, menutupi batuk atau bersin menggunakan siku, menggunakan hand sanitizer, menggunakan face shield untuk melindungi mata dan masker untuk menutupi hidung dan mulut mencegah masuknya partikel virus (Roy, 2020). Peralatan yang digunakan untuk melindungi diri disebut dengan PPE.

PPE (personal protective equipment) adalah alat pelindung diri dari infeksi dan penularan penyakit. Pertama kali, WHO (World Health Organization) mencetuskan PPE pada saat wabah filovirus Ebola di Afrika tahun 2013-2016 (Moran, 1987). Tenaga kesehatan yang melakukan kontak langsung dengan pasien memiliki resiko terinfeksi dan tertular yang tinggi. Penggunaan PPE merupakan solusi yang dilakukan untuk mencegah penyebaran dan penularan virus yang semakin luas.

Hal-hal yang harus diperhatikan dalam pembuatan PPE, antara lain: (1) dapat mencegah penularan virus ke penyedia layanan kesehatan; (2) memperhatikan kenyamanan pengguna; (3) ketangkasan, kemampuan untuk melakukan prosedur dan tugas, dan kemampuan untuk bergerak; (4) waktu toleransi maksimum untuk memakai peralatan dan dengan demikian tersedia untuk perawatan pasien (Moran, 1987). Berdasarkan pernyataan diatas dapat diketahui bahwa produk PPE harus terbuat dari bahan yang tahan terhadap air/ anti air, memiliki warna yang terang karena ketika terkontaminasi cairan maka akan mudah terlihat dan ringan dan nyaman untuk digunakan sehingga memudahkan untuk bergerak. Masker yang baik yaitu masker yang dibuat dengan minimal 3 lapis. Terdiri dari lapisan luar, lapisan dalam, dan filter. Hal ini dilakukan untuk memperkecil celah material dari partikel virus, bakteri, debu dan serbuk sari. Terdapat berbagai jenis masker yang baik digunakan untuk melindungi diri dari tingkat perlindungan yang paling kuat, yaitu: masker N95, masker bedah, masker FFP1, masker kain (minimal 3 lapis).

Keselamatan dan keamanan merupakan faktor utama demografi dan sosioekonomi di tengah permasalahan sosial dan politik sebagai akibat pandemi global. Sejak Maret 2020, penjualan PPE (personal protective equipment) seperti masker, sanitiser, busana pelindung diri, dan produk pembersih rumah mengalami peningkatan. Peningkatan penjualan produk tersebut sebagai akibat usaha untuk melindungi diri dan orang-orang terdekat, disamping itu untuk meningkatkan kontrol diri 
pada masa-masa penuh gejolak saat ini. Perubahan paling besar pada konsumsi produk kebersihan pribadi yaitu meningkat 50\%. Kemudian selanjutnya tingkat konsumsi makanan kaleng meningkat 25,2 \%. (Wright, Oliver; Blackburn, 2020). Pernyataan diatas juga mendasari konsep pelatihan yang memberikan solusi bisnis dalam bidang fesyen yaitu outer pelindung dan masker.

Berdasarkan hasil riset tersebut PPE merupakan alternatif produk yang dibutuhkan konsumen di masa krisis akibat pandemic (Zhou et al., 2005). Produsen dan pelaku industri fesyen dapat menjadikan PPE sebagai pilihan diversifikasi produk untuk menjaga kelangsungan usaha tetap terjaga. Produk PPE yang dikembangkan adalah yang dapat memenuhi kebutuhan konsumen seharihari. Produk tersebut diantaranya berupa jaket/ outer pelindung diri untuk perjalanan saat diluar rumah, produk makser non medis namun tetap memenuhi standar keamanan dan keselamatan, dan produk sanitizer. PPE yang dijadikan materi pelatihan untuk mitra pelaku usaha dari IFC Community Surabaya dikhususkan pada produk fesyen sehari-hari seperti outer pelindung diri dan masker.

Busana pelindung diri (personal protective equipment) yang dijadikan sebagai materi pelatihan adalah PPE yang diaplikasikan ke dalam fesyen untuk kebutuhan sehari-hari dengan konsep utilitarian, yakni lebih megutamakan fungsi dan efisiensi selain faktor estetis. Fungsi dan efisiensi produk menjadi faktor penting untuk memenuhi permintaan atas kebutuhan pasar di masa resesi saat ini. PPE untuk kebutuhan fesyen sehari-hari menyesuaikan dengan pergeseran gaya konsumsi pasar pada masa pandemik dan pasca pandemik yang lebih mengutamakan mengkonsumsi barang dan jasa esensial dengan mengutamakan kesehatan sesuai dengan prediksi yang disampaikan oleh tim ahli pada artikel dengan judul The State of Fashion 2020.

Pelaksanaan program PKM bagi mitra disertai dengan penyampaian materi pemasaran secara digital. Pandemi juga merubah cara konsumen dalam berbelanja barang dan jasa. Pembelian barang dan jasa secara online melalui platform digital menjadi alternatif yang aman bagi kesehatan dan efektif bagi konsumen. Industri fesyen sudah seharusnya beradaptasi dengan dan melakukan efektivitas melalui platform belanja virtual (Kumar, 2020).

Program PKM diselenggarakan atas respon permasalahan yang dihadapi oleh mitra. Solusi yang ditawarkan adalah memberikan sebuah pelatihan mulai dari desain, produksi, hingga sistem pemasaran yang sesuai dengan era new normal. Ide dan gagasan pelatihan dituangkan ke dalam bentuk pelatihan daring sebagai wujud mentaati aturan protokol kesehatan. Program pelatihan memberikan materi untuk memberikan peluang bagi mitra untuk melakukan diversifikasi produk. Penting bagi mitra untuk menyesuaikan sistem bisnis tidak hanya mempertahankan produk dan konsumen yang telah ada, tetapi mencoba untuk melakukan pengembangan untuk pasar baru yang belum terbentuk sebelumnya (Yuswohady et al., 2020).

Mitra yang terlibat dalam kegiatan PKM ini adalah Rangsit University Thailand dan Indonesian Fashion Chamber Community. Universitas Ciputra Surabaya bekerjasama dengan Rangsit University Thailand sebagai mitra pelaksana kegiatan. IFC Community merupakan mitra penerima manfaat dari kegiatan PKM. IFC Community Surabaya berkantor pusat di Surabaya, namun peserta pelatihan yang 
merupakan anggota IFC Community tersebar di beberapa kota seperti Surabaya, Sidoardjo, Nganjuk, dan Tulungagung. Kontribusi IFC Community adalah menerapkan hasil pelatihan untuk dapat maju bersama beradaptasi keluar dari krisis dengan mencoba menciptakan produk-produk sesuai kebutuhan pasar di era new normal.

Perumusan masalah adalah bagaimana kegiatan pelatihan desain fesyen dan produksi untuk menghasilkan alternative produk anggota IFC Community dalam beradaptasi dengan perubahan model bisnis akibat pandemi covid-19? Tujuan kegiatan adalah melalui kegiatan PKM khalayak sasaran (mitra) diharapkan mampu menganalisa adaptasi trend dan pasar khususnya di era new normal satu hingga dua tahun mendatang. Kemanfaatan dari program ini adalah khalayak sasaran mampu mendesain dan memproduksi beberapa prototipe busana pelindung diri yang relevan dengan fesyen sehari-hari berkonsep utilitarian. Selain itu diharapkan juga mampu memanajemen pemasaran produk khususnya melalui sistem daring. Tujuan pelaksanaan pelatihan adalah memberikan solusi sesuai permasalahan mitra. Solusi tersebut adalah sebagai berikut:

1. Memberikan pelatihan daring mengenai standarisasi busana dan aksesoris pelindung diri yang dapat diaplikasikan sebagai fesyen sehari-hari. Pelatihan meliputi bidang desain dan produksi.

2. Memberikan pelatihan daring mengenai manajemen dan branding produk fesyen di era new normal. Pelatihan ini meliputi pemanfaatan media sosial sebagai media promosi dan perencanaan pameran virtual melalui artstep.

3. Memberikan pelatihan daring mengenai pemanfaatan tekstil dan material adaptation untuk produk fesyen pelindung diri.

\section{METODE}

Metode pelaksanaan pelatihan desain dan produksi busana pelindung diri (PPE) untuk kebutuhan fesyen sehari-hari akan dilaksanakan secara daring melalui tahapan sebagai berikut:

1. Penyampaian materi melalui pelatihan daring menggunakan platform pertemuan virtual mengenai metodologi desain seperti riset, membaca kebutuhan dan peluang pasar, dan menuangkan inspirasi ke dalam desain. Materi metodologi desain fesyen meliputi brief inspirasi, riset, konsep moodboard, dan pengembangan desain (Aroyo, 2011).

2. Penyampaian materi melalui pelatihan daring mengenai tekstil dan material yang relevan untuk busana pelindung diri dan teknik produksinya. Pengetahuan tekstil penting dipahami agar desain PPE yang diproduksi memiliki material yang sesuai kebutuhan. Pengetahuan tekstil meliputi jenis serta, teknik produksi, karakter material, dan pengembangan smart-textile (Baugh, 2011).

3. Penyampaian materi melalui pelatihan daring mengenai konsep branding secara online dengan memanfaatkan media sosial. Peserta dilatih untuk dapat mengemas pameran virtual sebagai alternatif media pemasaran di masa pandemi. 
4. Modul pelatihan berupa panduan buku ajar disusun untuk dapat dimanfaatkan oleh mitra sebagai media pembelajaran. Selain itu, video tutorial juga disiapkan untuk memudahkan dalam penyampaian materi.

5. Partisipasi mitra adalah mengikuti setiap pelatihan daring sesuai dengan jadwal yang telah ditetapkan bersama. Mitra diharapkan mampu menghasilkan sebuah produk busana pelindung diri untuk keperluan sehari-hari sesuai standar protokol kesehatan dengan tetap mengedepankan fungsi dan nilai estetika sebagai salah satu nilai jual.

6. Setiap tahapan kegiatan didokumentasikan untuk dapat dievaluasi di tahap akhir pelatihan.

7. Pelaksana membagikan lembar evaluasi kepada mitra di tahap akhir pelatihan. Lembar evaluasi bertujuan untuk dapat mengetahui pencapaian dan juga hambatan yang dihadapi mitra agar dapat lebih dimaksimalkan pada program selanjutnya.

Jadwal pelatihan disusun berdasarkan time line alur kerja metodologi penciptaan desain fesyen. Time line pelatihan dibagi menjadi 3 tahap yaitu tahap koordinasi pra pelatihan, tahap pelatihan/ training, dan tahap evaluasi. Kegiatan pra pelatihan merupakan tahap koordinasi antara pelaksana dengan mitra. Tujuan pelaksanaan pelatihan dan target capaian kegiatan disampaikan pada tahap koordinasi agar mitra memiliki persamaan persepsi. Pelatihan dibagi kedalam tiga kali pertemuan secara daring. Materi riset dan pengembangan desain disampaikan pada tahap pertama pelatihan. Pada tahap ke dua dipaparkan materi mengenai produksi dan aplikasi material. Tahap ke tiga merupakan pelatihan branding dan marketing produk. Selama pelatihan berlangsung mitra diberikan kesempatan mentoring secara daring melalui platform chat online. Tahap akhir pelatihan adalah evaluasi kegiatan baik produk yang dihasilkan ataupun evaluasi mengenai pelaksanaan kegiatan.

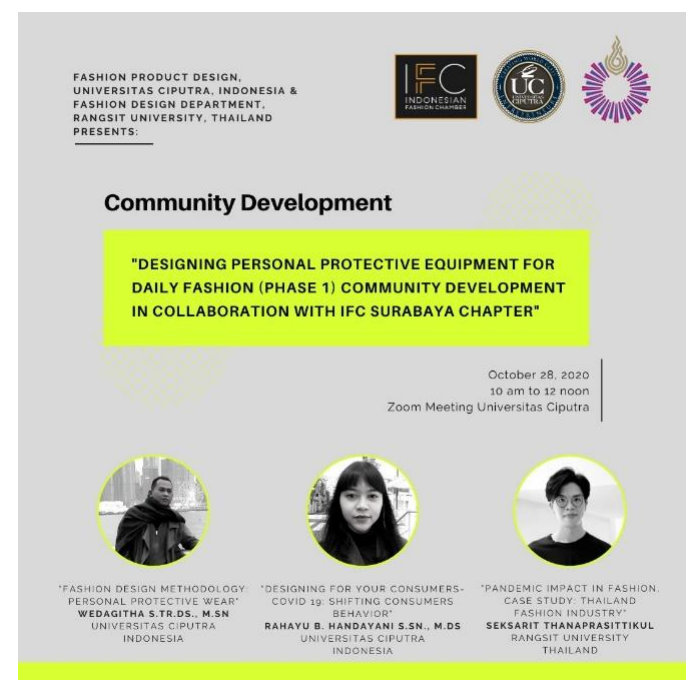

Gambar 1. Media Promosi Webinar 


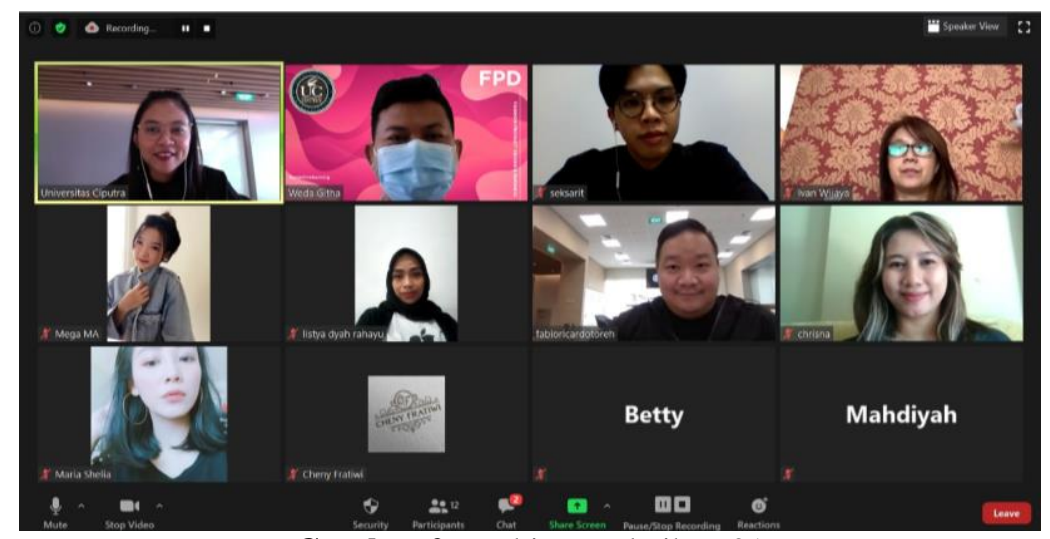

Gambar 2. Webinar Pelatihan 01

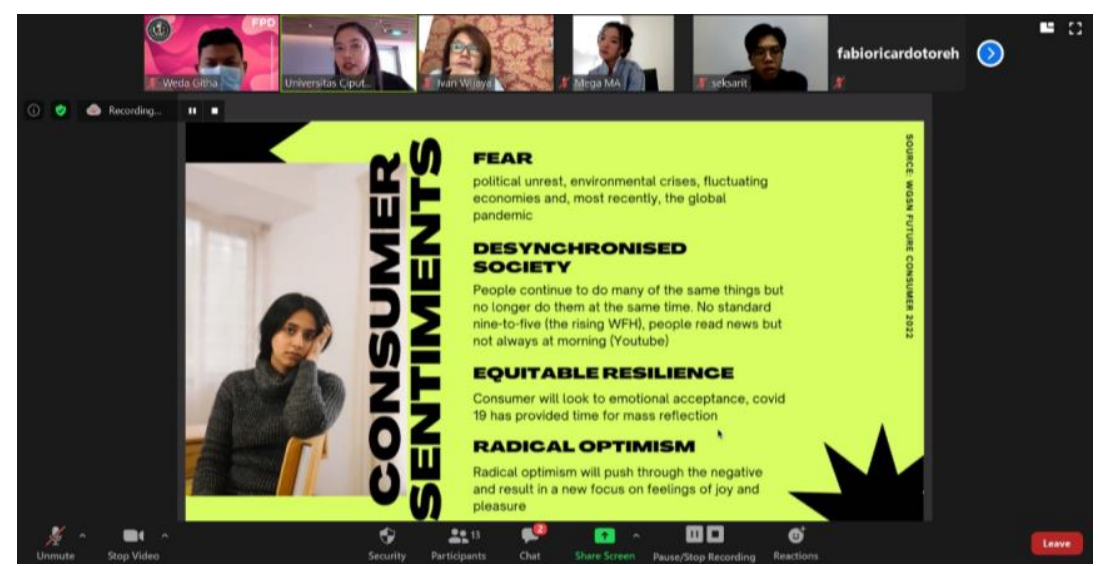

Gambar 3. Webinar Pelatihan 02

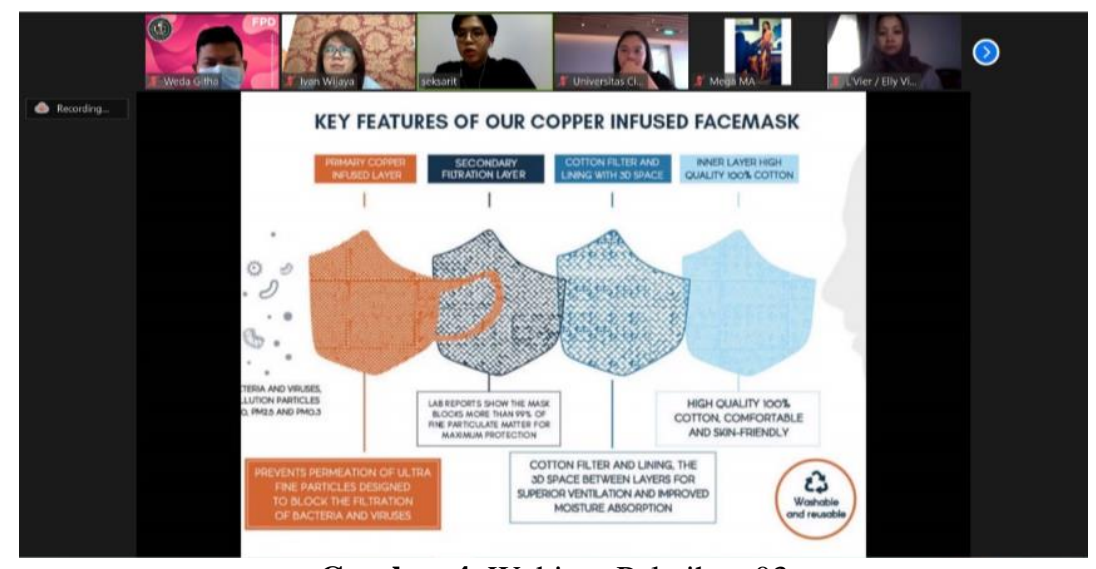

Gambar 4. Webinar Pelatihan 03 


\section{HASIL DAN PEMBAHASAN}

Pelaksanaan kegiatan pelatihan desain dan produksi busana pelindung diri untuk kebutuhan sehari-hari mampu memberi perubahan positif bagi mitra. Kegiatan pelatihan telah meningkatkan pengetahuan mitra dalam hal diversifikasi produk khususnya dalam merancang, memproduksi, hingga menyusun strategi pemasaran digital. Pengetahuan tersebut dinilai relevan sebagai salah satu solusi dalam beradaptasi di era normal baru. Mitra diharapkan mampu untuk mengembangkan dan mengaplikasikan pengetahuan yang diberikan melalui pelatihan dalam kegiatan bisnis mereka.

Pelaksanaan kegiatan pengabdian masyarakat kerjasama Universitas Ciputra dengan mitra IFC Community Surabaya menghasilkan beberapa capaian dan luaran sesuai dengan tujuan pelaksanaan pelatihan. Capaian tersebut antara lain sebagai berikut:

1. Sketsa pengembangan desain berdasarkan riset. Masing-masing kelompok peserta membuat 6 model pengembangan desain PPE (personal protective wear) untuk kebutuhan sehari-hari berupa outer dan masker. Desain menyesuaikan dengan konsep utilitarian yaitu mengutamakan fungsi selain faktor estetis. Pengembangan model berdasarkan hasil riset terhadap prediksi tren, perubahan perilaku pasar akibat pandemi, dan standar produk PPE untuk kebutuhan sehari-hari. Peserta pelatihan dinilai cukup mampu melakukan tahap peroses perancangan awal dari penetuan ide, mencari inspirasi, riset, hingga pengembangan desain. Berikut merupakan salah satu contoh desain untuk pelatihan perancangan PPE.

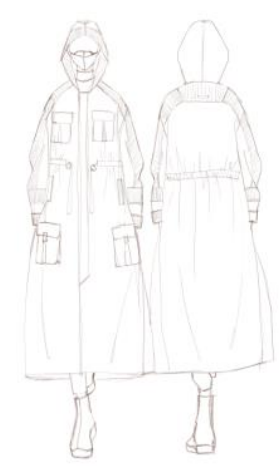

Gambar 5. Desain Pengembangan PPE

2. Produk PPE (personal protective equipment) untuk kebutuhan fesyen sehari-hari berupa outer atau jaket dan masker. Produk PPE hasil pelatihan mengolah material cleona yang diperoleh dari PT. Gistex dengan sifat kain anti virus, anti bakteria dan waterproof sesuai dengan kebutuhan dan aman digunakan sebagai busana pelindung untuk aktivitas sehari-hari. Bahan Cleona memiliki spesifikasi lebar bahan 55-56 inch, $115 \mathrm{gram} / \mathrm{m}^{2}, 100 \%$ poliester. PT. Gistex telah mendapatkan izin dari Kementrian Kesehatan Republik Indonesia dalam memproduksi dan mengedarkan bahan dan alat kesehatan. Produk PT. Gistex juga telah teruji ramah lingkungan. Material tersebut diolah sesuai pengembangan desain seperti diwarnai atau dicetak untuk menambah nilai estetika desain sehingga lebih komersil. Produk memiliki beberapa detail seperti 
kantong, hood pelindung kepala, bukaan di bagian depan, dan konsep desain unisex sesuai dengan tema utilitarian dan efisiensi desain di masa pandemik dan new normal. Produksi menyesuaikan dengan standarisasi PPE untuk kebutuhan fesyen sehari-hari. Produk desain terbaik didaftarkan hak cipta sebagai apresiasi kepada peserta.

3. Masing-masing kelompok peserta pelatihan menghasilkan pemetaan konsumen berdasarkan gambaran pasar yang menjadi sasaran di wilayah kota Surabaya dan sekitarnya. Pemetaan berdasarkan faktor demografis, psikografis, geografis, dan prilaku konsumen. Melalui pemetaan konsumen peserta menghasilkan strategi branding dan pemasaran sederhana untuk menyasar pasar yang dituju. Konsep branding memaksimalkan sosial media sebagai media promosi.

4. Hasil pelatihan juga berupa modul bahan ajar mengenai metode penciptaan desain yang disusun sederhana hingga mudah dipahami oleh peserta pelatihan.

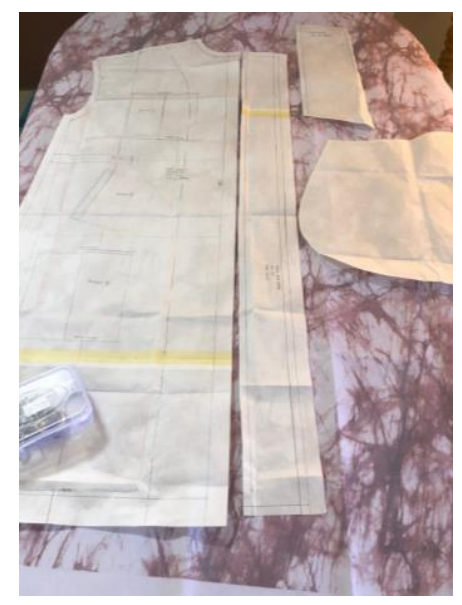

Gambar 6. Peletakan pola pada bahan cleona
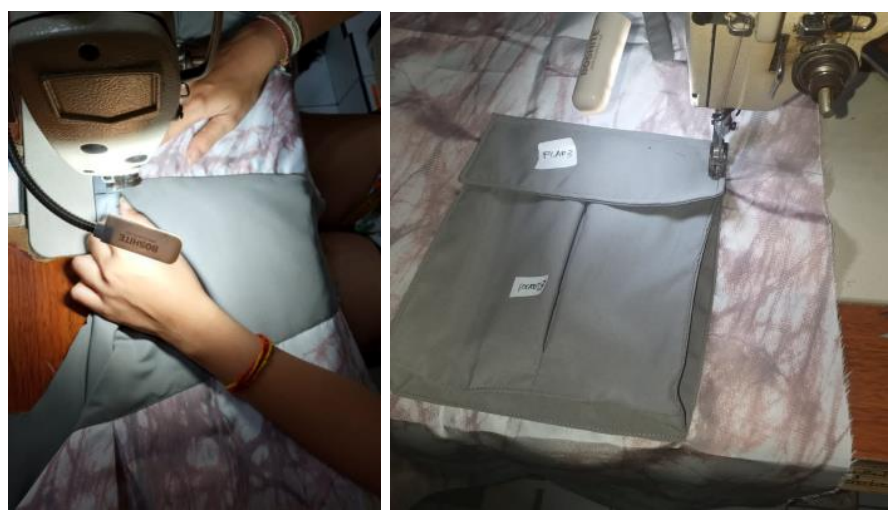

Gambar 7. Proses menjahit

Berikut merupakan hasil jadi dari pelatihan perancangan busana pelindung diri untuk fesyen sehari-hari. 


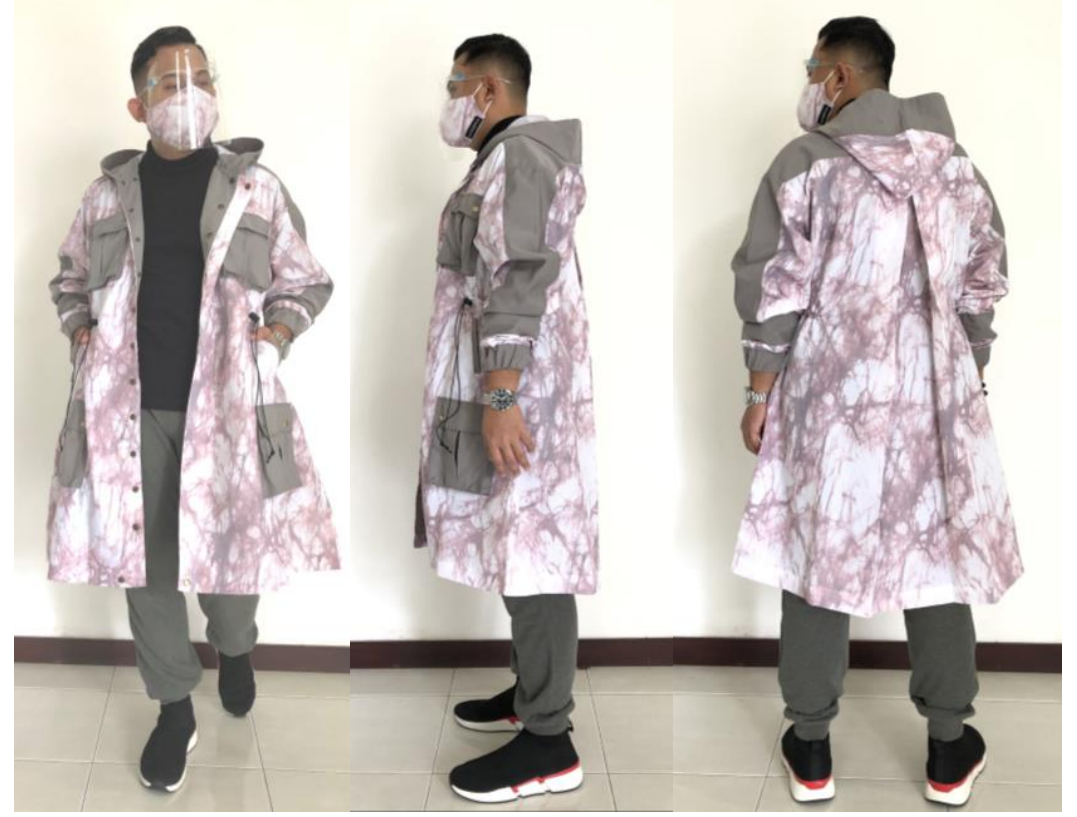

(a)

(b)

(c)

Gambar 7. PPE tampak (a) depan, (b) samping, (c) belakang

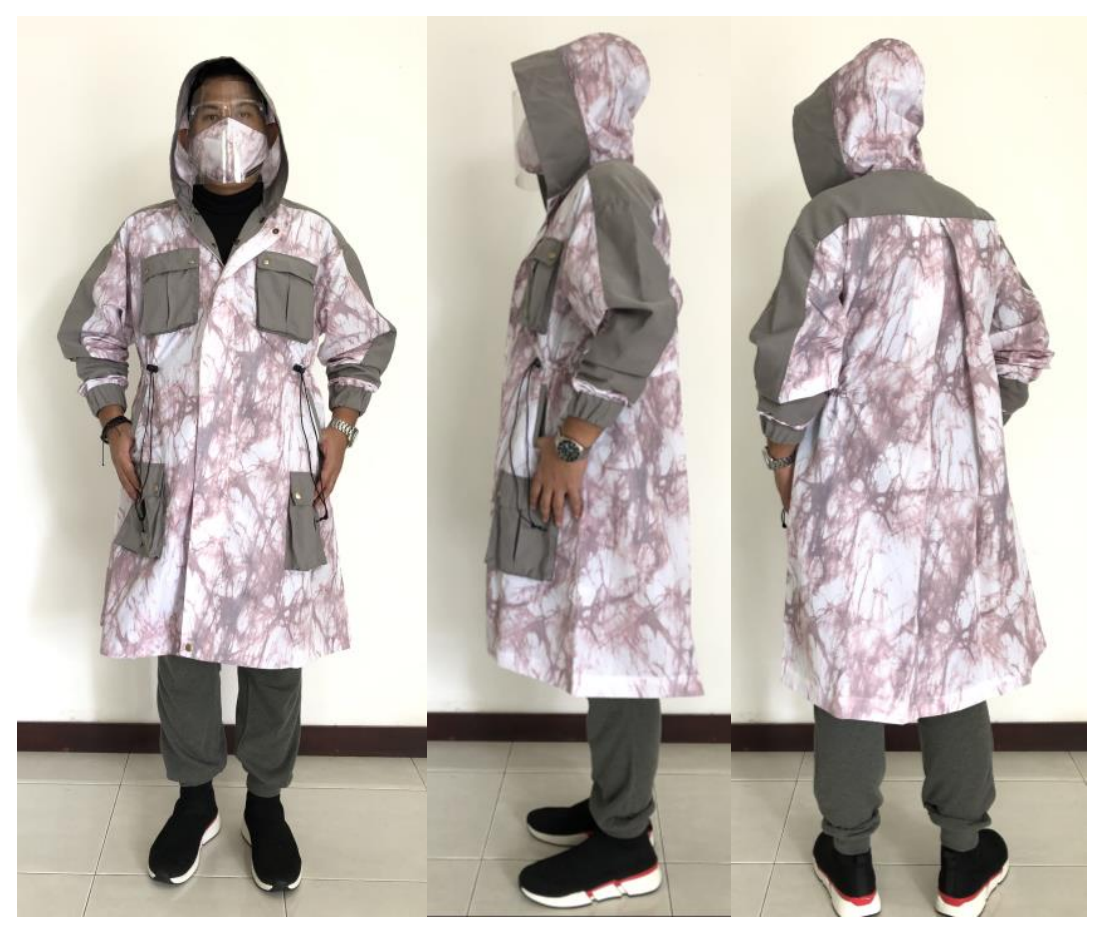

(a)

(b)

(c)

Gambar 8. PPE dengan hoodie tampak (a) depan, (b) samping, (c) belakang 


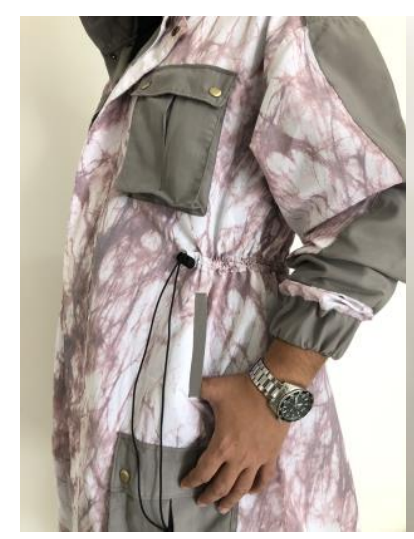

(a)

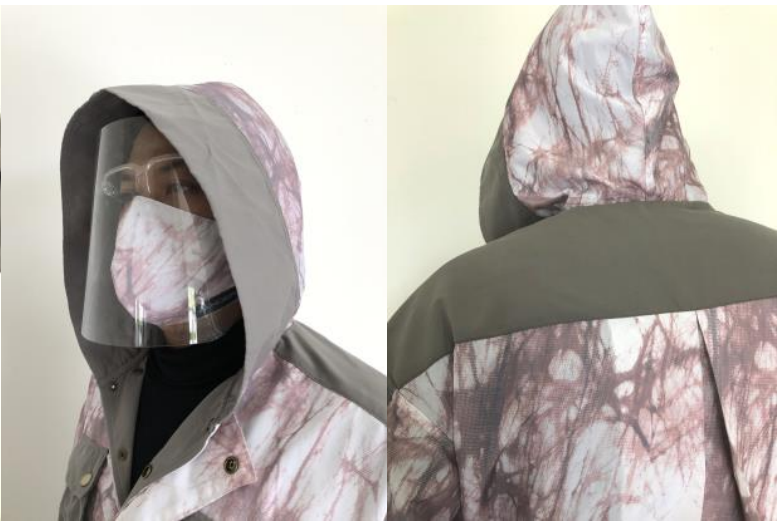

(c)

Gambar 9. Detail (a) kantong, tali serut, karet tangan,(b) hoodie dan masker, (c) bapang dan lipatan belakang

Keberhasilan kegiatan pelatihan diukur melalui indikator pencapaian tujuan pelaksanaan kegiatan. Indikator tersebut merupakan instrumen yang digunakan sebagai penilaian dalam keberhasilan mitra menerima dan mengaplikasikan materi pelatihan ke dalam luaran berupa produk busana pelindung diri untuk kebutuhan fesyen sehari-hari. Berikut merupakan tabel indikator penilaian pencapaian tujuan kegiatan:

Tabel 1. Indikator Keberhasilan

\begin{tabular}{|c|c|c|c|c|c|}
\hline NO & KRITERIA & \multicolumn{4}{|c|}{ INDIKATOR } \\
\hline \multirow[t]{3}{*}{1} & Desain & Konsep Desain & Capaian & $\begin{array}{c}\text { Kesesuaian Desain } \\
\text { dengan Tema }\end{array}$ & Capaian \\
\hline & & $\begin{array}{l}\text { Mampu menyusun ide serta } \\
\text { gagasan ke dalam sebuah } \\
\text { konsep desain dengan baik. } \\
\text { Penyusunan konsep meliputi } \\
\text { tahap metode penciptaan } \\
\text { desain; mampu menganalisa } \\
\text { masalah, mengembangkan } \\
\text { desain brief berupa mind } \\
\text { mapping, riset, dan } \\
\text { pengembangan desain. } \\
\text { Nilai }(75-100)\end{array}$ & $100 \%$ & $\begin{array}{l}\text { Mampu menciptakan } \\
\text { pengembangan desain } \\
\text { sesuai dengan konsep } \\
\text { desain. Pengembangan } \\
\text { desain meliputi pengolahan } \\
\text { elemen desain berdasarkan } \\
\text { prinsip desain sebagai } \\
\text { panduan. } \\
\text { Nilai }(75-100)\end{array}$ & $90 \%$ \\
\hline & & Kurang mampu menyusun & & Kurang mampu & $10 \%$ \\
\hline
\end{tabular}




\begin{tabular}{|c|c|c|c|c|c|}
\hline & & $\begin{array}{l}\text { ide serta gagasan ke dalam } \\
\text { sebuah konsep desain dengan } \\
\text { baik. Penyusunan konsep } \\
\text { meliputi tahap metode } \\
\text { penciptaan desain; mampu } \\
\text { menganalisa masalah, } \\
\text { mengembangkan desain brief } \\
\text { berupa mind mapping, riset, } \\
\text { dan pengembangan desain. } \\
\text { Nilai (30-74) }\end{array}$ & & $\begin{array}{l}\text { menciptakan } \\
\text { pengembangan desain } \\
\text { sesuai dengan konsep } \\
\text { desain. Pengembangan } \\
\text { desain meliputi pengolahan } \\
\text { elemen desain berdasarkan } \\
\text { prinsip desain sebagai } \\
\text { panduan. } \\
\text { Nilai }(30-74)\end{array}$ & \\
\hline & & $\begin{array}{l}\text { Tidak mampu menyusun ide } \\
\text { serta gagasan ke dalam } \\
\text { sebuah konsep desain dengan } \\
\text { baik. Penyusunan konsep } \\
\text { meliputi tahap metode } \\
\text { penciptaan desain; mampu } \\
\text { menganalisa masalah, } \\
\text { mengembangkan desain brief } \\
\text { berupa mind mapping, riset, } \\
\text { dan pengembangan desain. } \\
\text { Nilai }(0-29)\end{array}$ & - & \begin{tabular}{l}
\multicolumn{2}{l}{ Tidak mampu menciptakan } \\
pengembangan desain \\
sesuai dengan konsep \\
desain. Pengembangan \\
desain meliputi pengolahan \\
elemen desain berdasarkan \\
prinsip desain sebagai \\
panduan. \\
Nilai $(0-29)$
\end{tabular} & - \\
\hline 2 & Produksi & Eksplorasi Pola (Cutting) & Capaian & Teknik Produksi & Capaian \\
\hline & & $\begin{array}{l}\text { Mampu mengaplikasikan } \\
\text { desain ke dalam pecah pola } \\
\text { (cutting exploration). } \\
\text { Nilai }(75-100)\end{array}$ & $85 \%$ & $\begin{array}{l}\text { Teknik produksi dinilai } \\
\text { baik; kualitas produksi } \\
\text { baik, penggunaan material } \\
\text { (tekstil) yang sesuai, dan } \\
\text { sesuai standar pembuatan } \\
\text { PPE. } \\
\text { Nilai }(75-100)\end{array}$ & $70 \%$ \\
\hline & & $\begin{array}{l}\text { Kurang mampu } \\
\text { mengaplikasikan desain ke } \\
\text { dalam pecah pola (cutting } \\
\text { exploration). } \\
\text { Nilai (30-74) }\end{array}$ & $15 \%$ & $\begin{array}{l}\text { Teknik produksi dinilai } \\
\text { cukup; kualitas produksi } \\
\text { baik, penggunaan material } \\
\text { (tekstil) yang sesuai, dan } \\
\text { sesuai standar pembuatan } \\
\text { PPE. }\end{array}$ & $30 \%$ \\
\hline
\end{tabular}




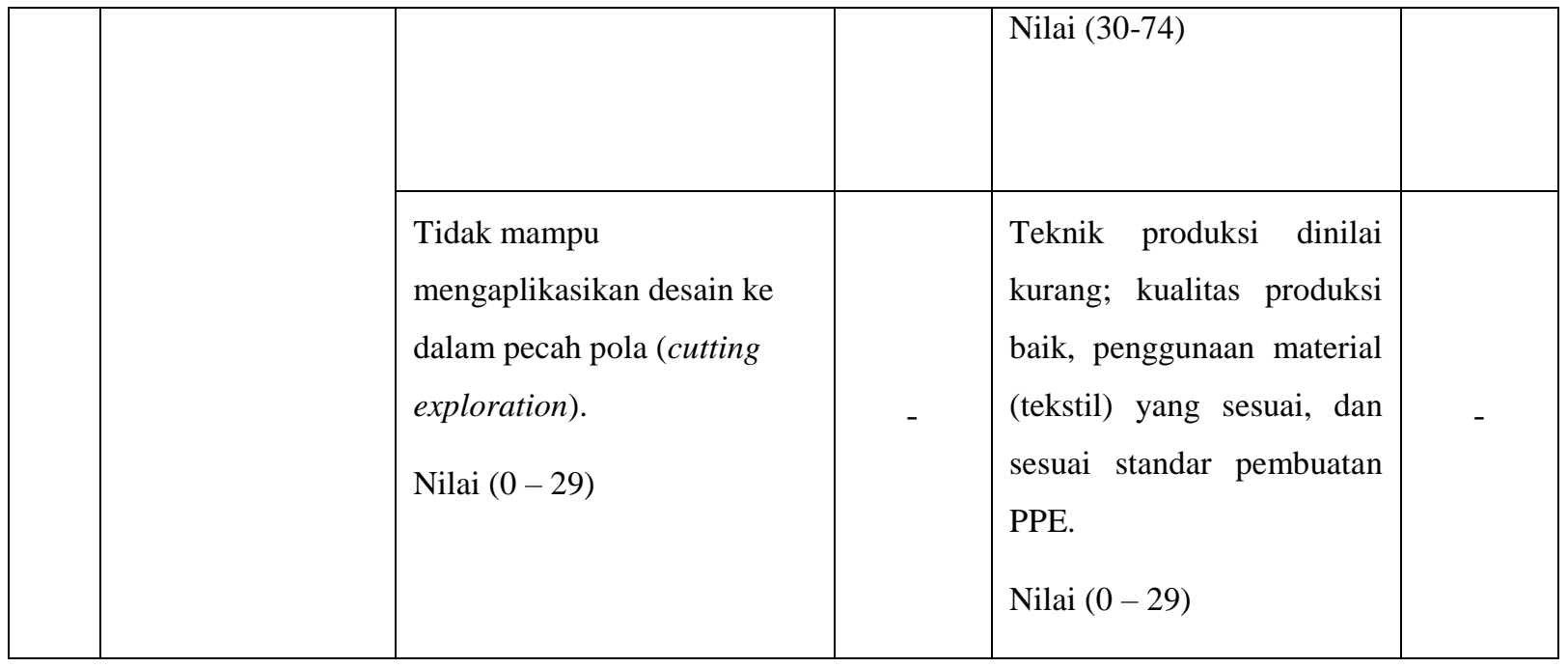

Keunggulan dan kelemahan luaran hasil pelatihan dapat dianalisa melalui tabel indikator pencapaian. Keunggulan luaran dapat diamati melalui pencapaian hasil desain produk yang beragam. Mitra mampu dalam menyusun gagasan menjadi sebuah konsep desain melalui riset seperti tren fesyen dan target pasar. Mitra mampu mengembangkan desain produk desain busana pelindung diri dengan mengolah dan mengatur komposisi elemen - elemen desain dengan baik. Kelemahan luaran terletak pada teknik produksi. Keterbatasan alat dan bahan menjadi penyebab produksi PPE fesyen tidak maksimal. Salah satu contoh adalah teknik jahit busana tidak disertai dengan proses rintang lubang jahitan (sealing) yang merupakan syarat utama produk PPE dalam menghambat pathogen dan mikroorganisme.

Tingkat kesulitan pengembangan produk ke depan disebabkan oleh beberapa faktor. Faktor pertama adalah kurangnya wawasan dan kesadaran masyarakat/ pasar dalam menerapkan protokol kesehatan ketika berada di luar ruangan. Perlu ada upaya mitra dalam melakukan promosi produk dengan konten promosi yang menekankan pada pentingnya pruduk pelindung diri dalam pelaksanaan protokol kesehatan. Faktor selanjutnya adalah keterbatasan ketersediaan alat dan bahan untuk teknik produksi yang sesuai standar. Upaya yang dilakukan adalah mengutamakan desain yang meminimalisir jahitan potongan sambung.

\section{KESIMPULAN}

Pelaksanaan kegiatan pelatihan desain dan produksi busana pelindung diri (PPE) untuk kebutuhan fesyen sehari-hari mampu menjadi salah satu alternatif solusi bagi permasalahan yang di hadapi mitra akibat pandemi Covid-19. Materi pelatihan dapat diterapkan sebagai alternatif produksi diversifikasi produk bagi pelaku usaha kecil menengah IFC Community Surabaya. Mitra mampu mendesain produk PPE berdasarkan riset dan membuat perencanaan promosi melalui media sosial. Pelaksanaan kegiatan pengabdian kepada masyarakat dapat berjalan efektif dan efisien dalam kondisi 
sesuai prosedur masa pandemi. Kegiatan pelatihan berdampak positif bagi mitra. Dampak positif tersebut adalah berupa wawasan peserta yang meningkat khususnya mengenai proses mendesain dan memproduksi busana PPE untuk kebutuhan fesyen. Selain itu peningkatan dapat dilihat pula melalui peningkatan kualitas produksi barang yang dihasilkan. Kendala dalam pelaksanaan seperti contoh pelatihan produksi mengalami sedikit kendala ketika dilaksanakan secara daring. Pelatihan PKM diharapkan tidak berhenti sampai di sini saja melainkan dapat dilanjutkan di masa mendatang sehingga potensi pelaku UKM khususnya IFC Community Surabaya semakin meningkat.

\section{UCAPAN TERIMAKASIH}

Tim pelaksana kegiatan pengabdian masyarakat mengucapkan terima kasih kepada semua pihak yang telah mendukung hingga pelaksanaan pelatihan dapat terwujud dan terlaksana dengan baik. Terima kasih kepada Lembaga Penelitian dan Pengabdian Masyarakat Universitas Ciputra Surabaya atas fasilitas dan dukungan pelaksanaan kegiatan, serta bantuan dalam pengurusan hak cipta karya desain. Terima kasih kepada tim pengajar dari jurusan Fashion Design Rangsit University Thailand sebagai mitra pelaksana kegiatan dan atas pengetahuan yang dibagikan ke peserta pelatihan. Pelaksanaan kegiatan tidak lengkap tanpa mitra penerima manfaat pelatihan. Untuk itu tidak lupa tim pelaksana mengucapkan terima kasih kepada Indonesian Fashion Chamber Surabaya khususnya IFC Community Surabaya sebagai peserta pelatihan dan atas semangat untuk tetap bergerak maju di masa krisis saat ini.

\section{DAFTAR PUSTAKA}

Aroyo, N. (2011). 1 Brief, 50 Designers Solutions in Fashion Design. Rockport Publishers.

Baugh, G. (2011). The Fashion Designer's Textile Directory. Thames \& Hudson Ltd.

Beltrami, M., Kim, D., \& Rolkens, F. (2020). The State of Fashion 2020. McKinsey\&Company, 1107.

Fauzia, M. (2020). Sri Mulyani Proyeksi Ekonomi Quartal III Minus 2,9 Persen, Siap-siap Resesi. Kompasiana 22 September 2020. https://money.kompas.com/read/2020/09/22/125539726/srimulyani-proyeksi-ekonomi-kuartal-iii-minus-29-persen-siap-siapresesi?page=all\#: :text=Benda hara Negara itu mengatakan $\% 2 \mathrm{C}$ pada,hingga minus $2 \% 2 \mathrm{C} 9$ persen

Hastuti, R. K. (2020). Apa sih Seramnya RI Resesi Ekonomi. CNBC Indonesia 3 Oktober 2020. https://www.cnbcindonesia.com/news/20201003084954-4-191567/apa-sih-seramnya-ri-resesiekonomi

Kumar, R. (2020). Effectiveness of Fashion Industry in Post Pandemic World. Journal of Textile Science \& Fashion Technology, 6(4), 1-6. https://doi.org/10.33552/jtsft.2020.06.000645

Moran, J. B. (1987). Personal protective equipment. Applied Industrial Hygiene, 2(5), R-5-R-6. https://doi.org/10.1080/08828032.1987.10390230

Roy, P. (2020). Face Mask: The New Normal Fashion Trends. Delhi Magazine 03 Agustus 2020. https://www.delhi-magazine.com/news/face-mask-the-new-normal-fashion-trends/ 
Wright, Oliver; Blackburn, E. (2020). How COVID-19 will permanently change consumer behavior. Accenture, April, 1-9. https://www.accenture.com/us-en/insights/retail/coronavirus-consumerbehavior-research\%0Ahttps://www.accenture.com/_acnmedia/PDF-134/Accenture-COVID19Consumer-Behaviour-Survey-Research-PoV.pdf\#zoom $=40$

Yuswohady, Brillian, G., Rachmaniar, A., \& Fatahillah, F. (2020). SURVIVAL TACTICS DURING COVID-19 CRISIS - The 50 Innovation Ideas that Matter (p. 84).

Zhou, W., Reddy, N., \& Yang, Y. (2005). Overview of protective clothing. Textiles for Protection, December, 3-30. https://doi.org/10.1533/9781845690977.1.3 